drawn with a rounded and not an angular or even perpendicular edge to the umbilicus as it should be. To judge from the figure, it would be a different form.

As to G. Aalense. If specimens with different-sized umbilicus, different character of ribbing, and different shape of inner edge, are all varieties of one species, and no indication given of what is the common feature that binds them all together, something further in the way of "proof" does seem possible.

$G$. subquadratum versus $G$. Scemanni. No two specimens of Ammonite are probably identical, but these seem to me (and that is all I say) to be so alike, even in the matter of coiling, after measurement, that no sensible differences can be appreciated from the figures.

On the question of the keel on the cast of a hollow-keeled Ammonite I am clearly in the wrong. I was certainly not aware that so well-marked a one could co-exist with a hollow keel above it, till Mr. Buckman was kind enough to send me a specimen in which the fact is indubitable.

3. Mr. Lydekker says that a superficial knowledge of the subject would enable any one to gauge the value of my criticisms. I do not think myself that it requires even a superficial knowledge to appreciate them, merely some common sense. It certainly never struck me that Orthopleurosaurus was meant for a simple rectification of Orthocosta, in spite of the somewhat superfluous remark that the latter is hybrid. The proper rectification, following the author's guidance of "polydens" changed to " multidens," would be Recticosta. We are not told whether this is objected to, or whether it and Orthopleurus are preoccupied, nor is any reason given why -saurus is added on, so that even now no reason is given for the actual result of the change.

4. Dr. Callaway has ordered pistols for two and coffee for one. But he scarcely expects me, I think, to accept his challenge. I have nothing to gain by doing so, if victorious. The fact is, I am so thoroughly convinced of my own power of making a mistake, even when it seems most obvious that I cannot have done so, that I never $\operatorname{come}$ to a conclusion of my own, much less propound one for the acceptance of others, till it rests on so many foundations that I ferl sure they cannot all be wrong; the advantage of which is that I can afford to give away a few, if contested, without the conclusion being much damaged. I do not by any means give away the observations in question; but if Dr. Callaway likes to take them, it is not worth while to run after him.

\title{
INOTICFS OF MFMIOIRS
}

\section{I.-Fossil Dragon-Flies.}

T $\mathrm{N}$ the following work-A Synonymic Catalogue of Neuroptera 1 odonata or Dragon-flies, by W. F. Kirby, F.L.S., etc., 8vo. Gurney \& Jackson, London, 1890-is an Appendix (pages 165176) enumerating all the known Fossil Odonata, with authorities, 
synonyms, geological stages, and localities. This useful catalogive comprises-Libellulidæ.-Libellulinæ: 3 genera, namely, Eschnidium (3 species), Libellulium (3 species), Libellnla (20 species). Libellulidæ.-Corduliinæ: 1 genus (2 spp.). Ashnidæ.-Gomphinæ, 10 genera; Ashna (3 spp.), Gomphoides (2 spp.), Ictinus (1 sp.), Protolindenia (1 sp.), Heterophlebia (7 spp.), Stenophlebia (5 spp.), Cordulegaster (3 spp.), Cymatophlehia (1 sp.), Uropetala (4 spp.), Petalura (3 spp.). Aschnidæ:-Eschninæ, 2 genera ; Anax (1 sp.), Aschna (11 spp.). Agrionidæ.-Agrioninæ, 3 genera; Isophlebia (2 spp.), Tarsophlebia (1 sp.), Euphæa (3 spp.). Agrionidæ.-Coenagrioninæ, 7 genera; Podagrion (1 sp.), Dysagrion (3 spp.), Coenagrion (10 spp.), Steropoides (1 sp.). Lithagrion (2 spp.), Agrionidium (1 sp.), Lestes (5 spp.).

Geologically the species appear to be distributed thus:-

Miocene: Eningen, 15; Schossnitz, 3; Auvergne, 1; The Brown

Coal, Rott \& Sieblos, 9 ; Amber, East Prussia, 3.

Oligocene: Radoboj, 3 ; Florissant, 7.

Focene: Provence, 1 ; Monte Bolca, 1; Wyoming, 3.

Cretaceous: Queensland, 1.

Purbeck : 7 , Dorset and Wilts.

Jurassic : 31, Solenbofen, Eichstädt, Pappenheim.

Lias, Upper : 3, Dumbleton.

Lias, Lower (and Rhætic) : 5, Strensham, Binton, Cheltenham, Schambelen.

T. R. J.

1I.-The Grology and Mineral Springs of Pantellaria. By CAv. G. Jervis, F.G.S. "The Mediterranean Naturalist," Malta, December 1st, 1891, Vol. I. No. 7, pp. 93-96.

DANTELLARIA, the largest of the outlying islands belonging to Sicily, and containing one of the twelve Sicilian volcanoes, lies 53 miles from Sicily, and 34 from the coast of Tunis. It is $8 \frac{1}{2}$ miles in length and $4 \frac{1}{2}$ in breadth, with an area of 25,423 acres. Its Montagna Grande rises 2742 feet, and it has other mountains of less height. The south and east sides have precipitous cliffs; but at the northern extremity the ground slopes gently downwards to the coast with its little port. The town of Pantellaria has 3167 inhabitants; and 4148 people live in the five country villages or groups of cottages. Volcanic rocks, and rich soil from their decomposition, constitute the country. The volcano itself had numerous prehistoric eruptions, from centre and sides. As a member of the Lipari, Vulcano, and Ischia system, it may not be regarded as quite extinct, especially since earthquake shocks, and a submarine eruption not far from the coast, occurred in October last. It may be noted that an upheaval of the sea-bed for 40 fathoms would convert the Adventure Bank, now about 40 miles from Pantellaria towards Marsala, into an island, 14 miles long, and 3 miles broad, and rising nearly 200 feet above sea-level. Thirty-seven miles N.E. of Pantellaria, and 25 miles from the south coast of Sicily, the Graham Shoal remains where the submarine volcano in 1831 formed the 
island which has since gradually disappeared. East of Pantellaria, in the direction of Malta, the little island Limosa is also volcanic, thus widening the extent of this volcanic region.

Like Ischia, Pantellaria has thermo-mineral springs, used formerly by the Romans and Arabs; and indeed of the same character as those of Vichy and Ischia; and, if the surroundings were rendered more favourable by the removal of the convict-station to some other Italian island, and if some little capital were then judiciously laid out, these medicinal waters might have much therapeutic and economic importance as a convenient Mediterranean resort. In the eastern part of the island are the Candarerldu de lu Bagnu; also the Bagnu or hot lake in an old orater; and the Acqua della Grotta di Gadir. At the S.W. end of the island is the Acqua della Cala Nità, the hottest of all; not far off the Acqua del Porto di Saura Basso; and northwards, about five miles from town, is the Acqua salina di Sataria. There are also fumaroli, or emanations of aqueous vapour. One, termed Bagno secco, is in a cave, forming a Stufa or Sulatorium.

Some sulphur occurs in old fumaroles. The alkaline bicarbonates in the Candareddu de lu Bagnu and the Cala Nità transform the silica of the rock into soluble gelatinous silica, and then deposits it as a dirty-white or grey opal. Obsidian, pozzolana, pumice, and some special minerals also occur in the island. The mineral wealth and springs of Sicily and Pantellaria are described in Mr. Jervis's "Mineral Waters of Southern Italy," and "Subterranean Treasures of Italy." 1

T. R. J.

III.-The Existence of Numerous Rabrolaria in the Jurassic and the Eocene of the Nortu of France. By L. Cayeux. (Annales de la Société Géologique du Nord, Vol. XIX. 1891, pp. 300-315.)

$\S$ I. M. Cayeux bas found Radiolaria (1) In some Eocene tuffeaus (tufaceous limestones); (2). In the Oxfordian "gaize" (clay) with Ammonites Lamberti. They will be described in detail by-andbye. 1. The rocks improperly termed "tuffeaux" consist of organic debris with a siliceous cement. The organisms are Sponge spicules, a few Diatomaceæ, and a large number of various spheroidal skeletons of Radiolaria, belonging to Häckel's Monospharida and Dispharida. A. The Landenian Tuffeau at Bouchevesnes has about a sixth of its bulk made up of Radiolaria; at Malincourt Tournay, Lille, Angre, and Radinghem they are rare. $B$. The Ypresian Tuffeau of Montdes-Cats.

These discoveries in the Lower Eocene are important in as much as the Radiolaria described by Shrubsole from the London Clay are the only other Eocene forms known, if those described from the jasper of Tuscany be really Jurassic as regarded by Rüst and Häckel.

2. Radiolaria have been found in the Oxfordian Clay at Launois, Lalobbe, and La Neuville (Ardennes). Microscopic sections of small hard morsels of this "gaize" show a somewhat similar structure to

1 Geological Mag. 1889, pp. 176-177. 
that of the "tuffeaux"; but quartz and otber minerals are less abundant, Sponge spicules rarer, and Diatoms are absent, whilst Radiolaria make up a third or even a half. The minute sphæroidal objects are less globular and smaller; but, when isolated, prove to be Radiolaria of Häckel's Spharide group, a large number belonging to the Dispharida. M. Cayeux has not found Radiolaria in the Cretaceous "gaizes." Dr. Rüst has discovered quantities in the Jurassic jaspers, flints, cherts, etc., of Hanover, Bavaria, the Tyrol, eto. The Oxfordian clays above mentioned are to be regarded as ranking with Häckel's "mixed Radiolarian rocks"; not being so rich as "the pure Radiolarian rocks" of Nikobar (Oligocene), Barbadoes (Miocene), and the Jura (Jurassic); and therefore deposited at a less depth than 2000 fathoms, to which condition the included quartz sand also has reference.

$\$$ II. The probable origin of the silica in the Gaize and the Tuffeaux. M. Cayeux, previously treating of the microscopic fossils of the tuffeau and gaize, and of the Meule (Millstone) of Bracquegnies, showed that there are Sponges in each of these, that there are Sponges and Radiolarians in the "gaize," and, besides these, numerous Diatoms in the "tuffeau." These organisms naturally secreted silica from the sea-water, and left it when they died. The origin of the flint of the Chalk is here referred to this kind of intervention on the part of Sponges, and the silica of the tuffeaux and gaizes to the above-mentioned siliceous organisms. In these opinions the author finds support in conclusions arrived at by Dr. Hinde and Messrs. Jukes-Browne and Hill.

T. R. J.

\section{REVI耳WS.}

\section{I.-Note on the Discovery of Clymenia in North America.}

THE recent discovery of Clymenia in the Upper Devonian (Intumescens-zone) of Western New York by Mr. John M. Clarke is as unexpected as it is interesting. ${ }^{1}$ The Clymenia was found in a calcareous concretion in Shurtleff's Gully, Livingston County, New York," not far up in the shales of the Naples Beds," and was accompanied by specimens of Gephyroceras, Tornoceras, ${ }^{2}$ Bactrites, sp. nov. (near to B. carinatus, Münst.), Loxonema Noe, Clarke, Palaotrochus pracursor, Clarke, Platystoma minutissimum, Clarke, etc. The specimens comprised "about thirty examples of a single species [Clymenia (Cyrtoclymenia) Neapolitana, sp. nov.] in an exceptionally fine condition of preservation, affording the various stages of growth from the protoconch to maturity." The species is remarkably small, the largest mature individual collected having a diameter of only 14 millimetres. The umbilicus is wide, exposing all the volutions, the number of which is $5 \frac{1}{2}$ or 6 . The whorls are flattened on the

I See Amer. Journ. Sci. Jan. 1892, vol. xliii. p. 57.

2 It may be well to explain that the names Gephyroceras and Tornoceras apply to genera of Goniatites, erected by Hyatt out of the old genus Goniatites. 